\title{
Discovery and characterization of benzyloxy piperidine based dopamine 4 receptor antagonists
}

\author{
Kirsten T. Tolentino ${ }^{\mathrm{a}, \int}$, Viktoriya Mashinson ${ }^{\mathrm{a}, \int}$, Anish K. Vadukoot ${ }^{\mathrm{a}}$, and Corey R. Hopkins ${ }^{\mathrm{a}}$ \\ ${ }^{a}$ Department of Pharmaceutical Sciences, College of Pharmacy, University of Nebraska Medical Center, Omaha, NE \\ USA \\ SThese authors contributed equally to this work
}

\begin{abstract}
The dopamine receptor $4\left(\mathrm{D}_{4} \mathrm{R}\right)$ is highly expressed in both motor, associative and limbic subdivisions of the coritico-basal ganglia network. Due to the distribution in the brain, there is mounting evidence pointing to a role for the $\mathrm{D}_{4} \mathrm{R}$ in the modulation of this network and its subsequent involvement in L-DOPA induced dyskinesias in Parkinson's disease. As part of our continued effort in the discovery of novel $\mathrm{D}_{4} \mathrm{R}$ antagonists, we report the discovery and characterization of a new 3- or 4-benzyloxypiperidine scaffold as $\mathrm{D}_{4} \mathrm{R}$ antagonists. We report several $\mathrm{D}_{4} \mathrm{R}$ selective compounds ( $>30$-fold vs. other dopamine receptor subtypes) with improved in vitro and in vivo stability over previously reported $\mathrm{D}_{4} \mathrm{R}$ antagonists.
\end{abstract}

Keywords: Dopamine 4 receptor, D4R, antagonists, benzyloxypiperidine, Parkinson's disease

\section{Introduction:}

Dopamine (DA) is a catecholamine neurotransmitter, first recognized in the 1950s, and is the major neurotransmitter in the central nervous system $(\mathrm{CNS}){ }^{1}$ The dopamine receptors (DR) were first characterized as members of the Class A G-protein-coupled receptors (GPCRs) superfamily in the 1980s and $1990 \mathrm{~s}$, and they are subdivided into five subtypes, $\mathrm{D}_{1-5 .} .^{2,3}$ The five subtypes are further divided into two distinct families ( $\mathrm{D}_{1}$-like and $\mathrm{D}_{2}$-like) based on whether they activate or inhibit adenyl cyclase activity. The $\mathrm{D}_{1}$-like family consists of the adenyl cyclase activators $\mathrm{D}_{1}$ and $\mathrm{D}_{5}$, and the $\mathrm{D}_{2}$-like family consists of the adenyl cyclase inhibitors $\mathrm{D}_{2}, \mathrm{D}_{3}$, and $\mathrm{D}_{4} .^{3}$ There is high homology between the dopamine receptors with $\sim 80 \%$ homology between the $\mathrm{D}_{1}$-like receptors and $\sim 75 \%$ homology within the $\mathrm{D}_{2}$-like family. Although 
there are several approved therapies targeting the DRs, this high level of homology has made it difficult to identify subtype selective dopamine ligands.

The approved medications that modulate DRs are for schizophrenia (SZ), Parkinson's disease (PD) and others; however, very few are selective within the DRs, nor are they selective against the biogenic amine receptors. ${ }^{2,4,5}$ The early work on the discovery of DR modulators centered on the dopamine hypothesis of schizophrenia and most of the work was focused on the $D_{1}, D_{2}$, and $D_{3}$ receptors. ${ }^{6,7}$ The $D_{4} R$ has not been as extensively studied as the other DRs, although a few compounds were brought to clinical evaluation for SZ, but these failed due to a lack of efficacy. ${ }^{8-10}$ Based on the localization of the $\mathrm{D}_{4} \mathrm{R}$ in the brain, we, and others, have a renewed interest in the identification of selective $\mathrm{D}_{4} \mathrm{R}$ antagonists as tool compounds, and potential treatments, for other CNS diseases such as addiction, cancer and PD L-DOPA-induced dyskinesias (LID). ${ }^{11}$ Herein we report additional work in the discovery of new piperidine based ligands as $\mathrm{D}_{4} \mathrm{R}$ antagonists.

Initial work from our laboratory established the morpholine scaffold as a potent $\mathrm{D}_{4} \mathrm{R}$ antagonist resulting in the discovery of $\mathbf{1}$, a potent and selective $\mathrm{D}_{4} \mathrm{R}$ antagonist (Figure 1). ${ }^{12}$ Further in vivo work utilizing a 6-OHDA mouse model showed that 1 produced a dose-dependent reduction in dyskinesia AIM (abnormal involuntary movement) scores. ${ }^{13}$ Although this was an important tool compound, 1 suffers from significant liabilities limiting the progression of this compound (high intrinsic clearance). In addition to the morpholine, our laboratory has published a 4,4-difluoropiperidine scaffold (not shown) which produced very potent compounds; however, the fluorine atoms attenuated the basicity of nitrogen which led to a drastic reduction in brain penetration $(\operatorname{cog} \mathrm{P}>5) .{ }^{14}$ These compounds also suffered from high intrinsic clearance. Thus, we set out to explore additional scaffolds to probe the structure-activity relationship (SAR). 


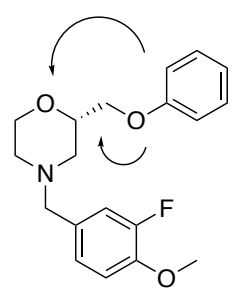

1

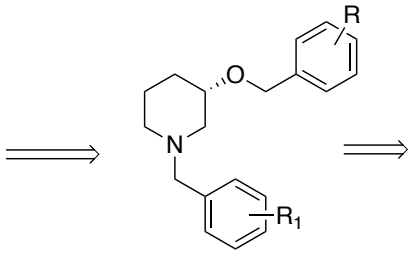

2

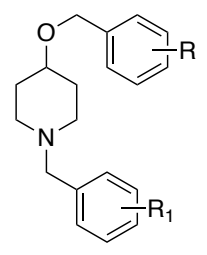

3

Figure 1.

The synthesis of the molecules in this study is shown in Scheme 1. Starting with the commercially available tert-butyl (S)-3-hydroxy or 4-hydroxypiperidine-1-carboxylate, $\mathbf{4}$ or $\mathbf{5}$, which were alkylated with $\mathrm{NaH}$ and the respective $\mathrm{BnBr}$ to form the benzyl ethers, followed by Boc deprotection to yield $\mathbf{6}$ or 7. ${ }^{12,15}$ Next, the final targets, 8 or $\mathbf{9}$, were realized by either (a) $\mathrm{N}$-alkylation $\left(\mathrm{Cs}_{2} \mathrm{CO}_{3}\right.$ and $\mathrm{BnBr}$ ) or (b) under reductive amination protocols $\left(\mathrm{Et}_{3} \mathrm{~N}, \mathrm{ArCHO}, \mathrm{NaHB}(\mathrm{OAc})_{3 .}{ }^{16}\right.$ Lastly, the phenyl acetamides, 11, were synthesized by direct $N$-alkylation of the requisite 2-chloroacetamides, $\mathbf{1 0}$, under basic conditions. ${ }^{17}$
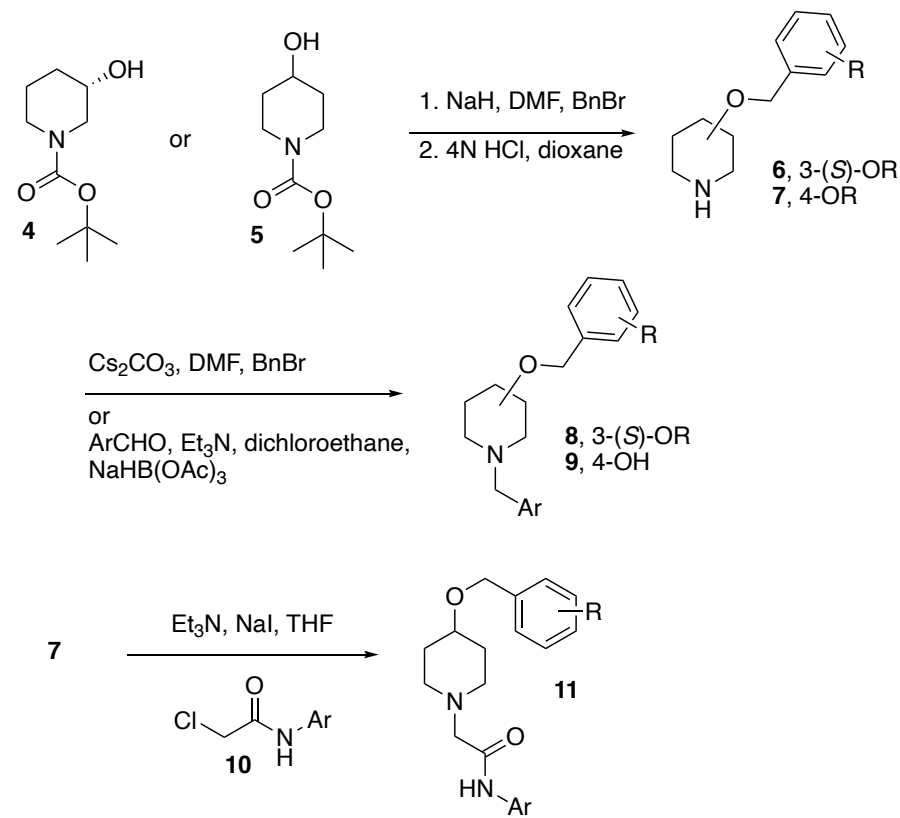

Scheme 1. Synthesis of the 3-(S)- or 4-ether piperidines, 8, 9, or 11.

Based on our previous work, we concentrated our SAR on a two-pronged approach by modifying both the nitrogen and oxygen substituents of the molecules (Table 1). ${ }^{12,14}$ The oxygen group modification centered around aryl and heteroaryl groups containing both electron-donating and electron-withdrawing groups. The nitrogen substituent moieties consisted of the best groups that we have identified previously. 
Starting with the $\mathrm{N}$-3-fluoro-4-methoxybenzyl group, we explored the $O$-alkylated area utilizing the benzyl groups that had previously provided active compounds. The 3-fluorobenzyl, 8a, showed good activity ( $\mathrm{K}_{\mathrm{i}}$ $=205.9 \mathrm{nM})$, and gratifyingly was selective against the other dopamine receptors $\left(\mathrm{D}_{1-3,5}\right)$. Adding an additional fluoro (3,4-difluorophenyl, 8b, $\mathrm{K}_{\mathrm{i}}=169 \mathrm{nM}$ ), methyl group (4-fluoro-3-methyl, 8c, $\mathrm{K}_{\mathrm{i}}=135$ $\mathrm{nM})$ or having a 4-methylbenzyl $\left(\mathbf{8 d}, \mathrm{K}_{\mathrm{i}}=241 \mathrm{nM}\right)$ or 2-methylbenzyl $\left(\mathbf{8 e}, \mathrm{K}_{\mathrm{i}}=343 \mathrm{nM}\right)$ all produced active compounds, although there was a slight loss of activity with the 2-methyl group. However, the 6methyl-2-pyridine, 8f, lost significant activity $\left(\mathrm{K}_{\mathrm{i}}=1,040 \mathrm{nM}\right)$. We have not previously looked at electron rich pyridines; however, compounds with an electron deficient pyridine (6-fluoro-2-pyridine) were active analogs in the morpholine scaffold. As with 8a, all the compounds were selective against the other dopamine receptors. Moving to the 2-methylimidazo[1,2- $a]$ pyridine we saw activity divergence compared to the 3-fluoro-4-methoxybenzyl group. The 3-fluorobenzyl compound, $\mathbf{8 g}$, was significantly less active $\left(\mathrm{K}_{\mathrm{i}}=1,939 \mathrm{nM}\right)$ than the corresponding 8a. However, the potency could be regained by an additional fluorine $\left(\mathbf{8 h}, \mathrm{K}_{\mathrm{i}}=375 \mathrm{nM}\right)$. The 4-fluoro-3-methylbenzyl was also active (8i, $\left.\mathrm{K}_{\mathrm{i}}=188 \mathrm{nM}\right)$; however, the 2-methylbenzyl lost activity and the 6-methyl-2-pyridine was again less active. The 3trifluoromethoxybenzyl, 81, was modestly active $\left(\mathrm{K}_{\mathrm{i}}=646 \mathrm{nM}\right)$. The next analogs, 1-methyl and 3methylimidazo[1,5-a]pyridine, showed a similar SAR pattern with the 3,4-difluorobenzyl $\left(\mathbf{8 n}, \mathrm{K}_{\mathrm{i}}=447\right.$ $\mathrm{nM})$ and the 4-fluoro-3-methylbenzyl $\left(\mathbf{8 o}, \mathrm{K}_{\mathrm{i}}=166 \mathrm{nM}\right)$ being the most active and the 3-methylbenzyl, 8m, 3-trifluoromethoxybenzyl, 8p, and 6-methyl-2-pyridine, 8q, being much less active or inactive. Interestingly, the 6-methyl-2-pyridine substituent was active when coupled with the 6-chloro-2-indole moiety, $\mathbf{8 r}\left(\mathrm{K}_{\mathrm{i}}=319 \mathrm{nM}\right)$. We then analyzed a variety of different $N$-benzyl substituents $(\mathbf{8 s - 8 a a})$ and only found a single compound that retained activity $\left(8 \mathrm{v}, \mathrm{K}_{\mathrm{i}}=165 \mathrm{nM}\right)$. Lastly, we looked at direct phenyl substitution at the nitrogen; however, these compounds were not active. It is of note that all the 3-O-benzyl derivatives, regardless of the $N$-substitution were selective against the other dopamine receptors. In addition, as these compounds are targeting a central nervous system (CNS) target, we evaluated the multiparameter optimization (CNS MPO) score as a tool to assess the druglike attributes. ${ }^{18,19}$ In this metric, compounds with scores $>4$ are considered to have a higher probability of success as CNS candidates. 
Compound 1 had a high (4.7) score, but the initial compounds, 8a-f, had lower scores that were predominantly driven by higher $\operatorname{cLog} \mathrm{P}$ and $\operatorname{cLogD}$ scores due to higher lipophilicity. The next set of compounds (8g-r) where more polarity was introduced either through the pyridine or the imidazopyridine moieties all delivered higher CNS MPO scores (>4.5). And, finally, the last set of compounds all had lower scores, again due to the higher $\mathrm{cLogP}$ and cLog D scores (8s-ab).

Table 1. (S)-3-O-piperidine

\begin{tabular}{|c|c|c|c|c|}
\hline Cmpd & Structure & $\begin{array}{c}\mathrm{D}_{4}, \mathrm{~K}_{\mathrm{i}}(\mathrm{nM}) \\
\text { or } \% \\
\text { inhibition at } \\
10 \mu \mathrm{M}^{a} \\
\end{array}$ & $\begin{array}{c}\text { DR, \% Inh @ } \\
10 \mu \mathrm{M}(\mathrm{nM})\end{array}$ & CNS MPO \\
\hline 1 & & $\begin{array}{c}5.8 \mathrm{nM} \\
\mathrm{pIC}_{50}=-8.30\end{array}$ & $<50 \%$ & 4.7 \\
\hline $8 a$ & & $\begin{array}{c}205.9 \\
\mathrm{pIC}_{50}=-6.69\end{array}$ & $<50 \%$ & 3.6 \\
\hline $8 b$ & & $\begin{array}{c}169.3 \\
\mathrm{pIC}_{50}=-6.77\end{array}$ & $<50 \%$ & 3.4 \\
\hline $8 c$ & & $\begin{array}{c}135.0 \\
\mathrm{pIC}_{50}=-6.87\end{array}$ & $<50 \%$ & 3.2 \\
\hline $8 \mathrm{~d}$ & & $\begin{array}{c}241.4 \\
\mathrm{pIC}_{50}=-6.62\end{array}$ & $<50 \%$ & 3.3 \\
\hline $8 \mathrm{e}$ & & $\begin{array}{c}343.1 \\
\mathrm{pIC}_{50}=-6.46\end{array}$ & $<50 \%$ & 3.3 \\
\hline $8 \mathrm{f}$ & & $\begin{array}{c}1,040.2 \\
\mathrm{pIC}_{50}=-5.98\end{array}$ & $<50 \%$ & 5.4 \\
\hline
\end{tabular}




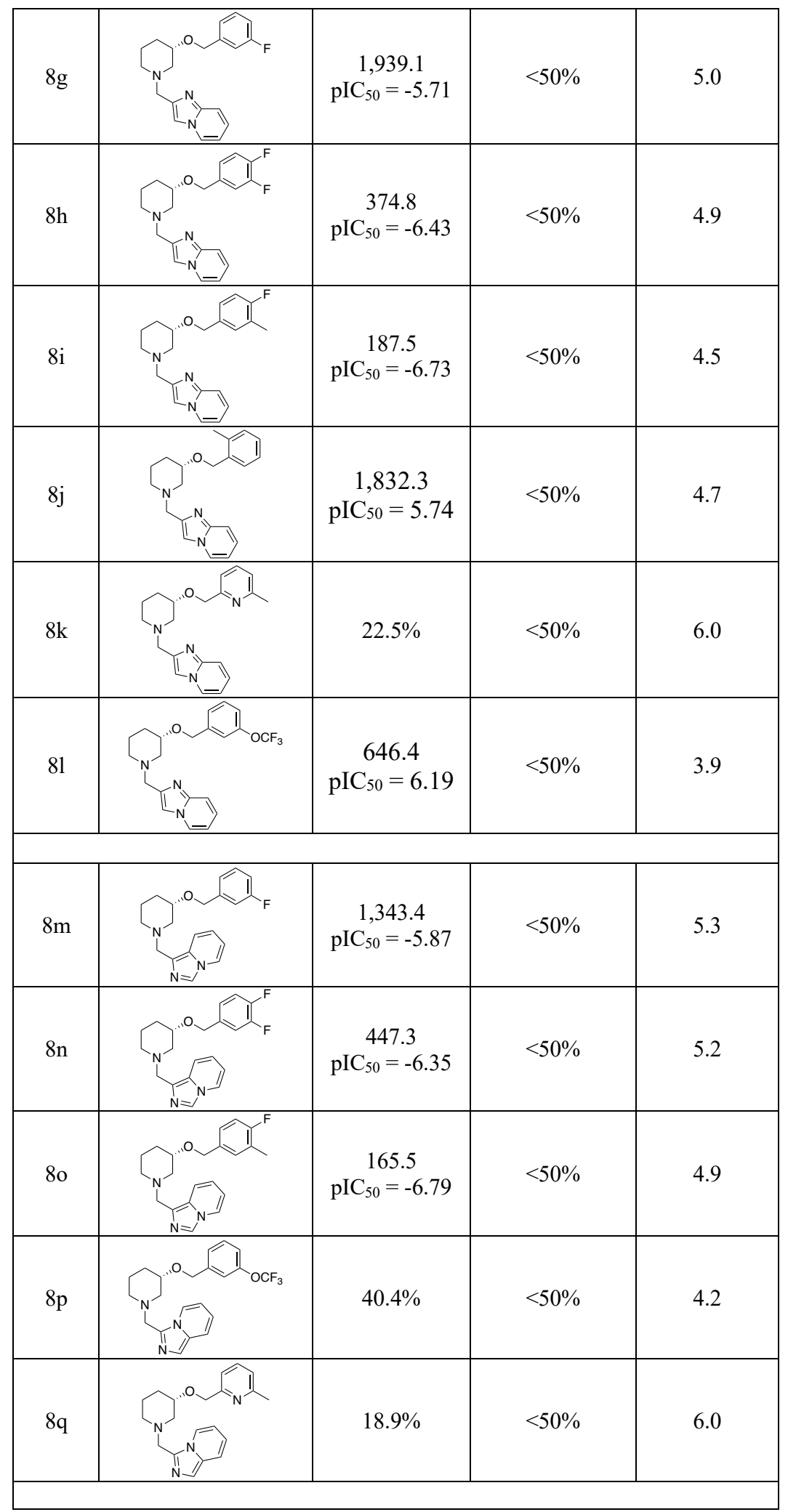




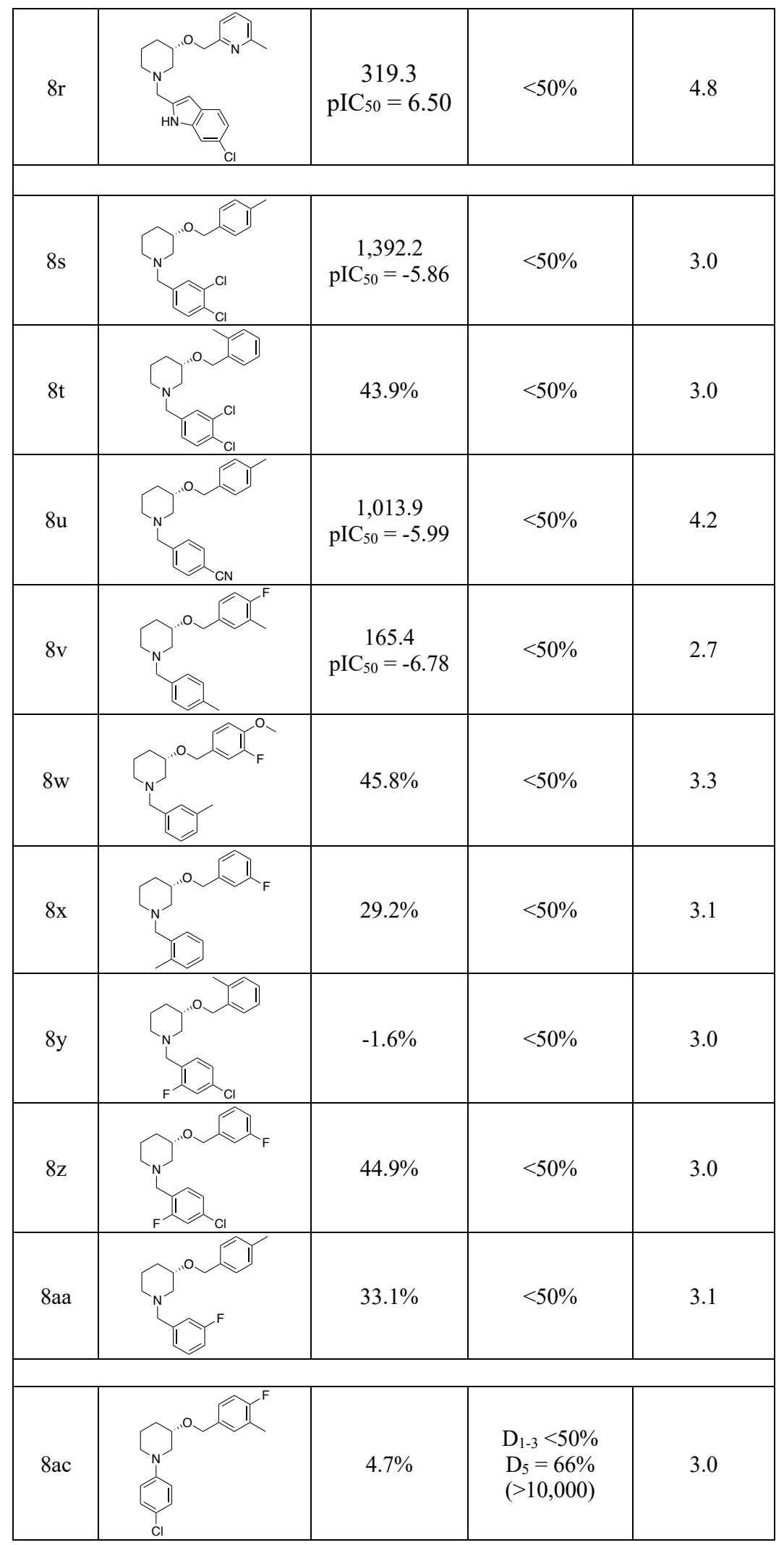




\begin{tabular}{|c|c|c|c|}
\hline 8ad & $-10 \%$ & $\begin{array}{c}\mathrm{D}_{1,2,5}<50 \% \\
\mathrm{D}_{3}=71 \%\end{array}$ & 3.0 \\
& & $(>10,000)$ & \\
\hline
\end{tabular}

Moving to the 4-oxopiperidine scaffold we kept the same strategy and looked at varying both the 4-oxygen and the piperidine nitrogen in a systematic fashion that utilizes key moieties that were shown to impart activity in previous scaffolds (Table 2). We started with the 2-imidazo[1,2-a]pyridine southern portion and evaluated halogenated benzyl groups, 9a-9d. The 3-fluorobenzyl, 9a $\left(\mathrm{K}_{\mathrm{i}}=167\right.$ $\mathrm{nM}$ ), activity was vastly improved from the 3 - $O$-derivative, $\mathbf{8 g}$, by 10 -fold. Adding an additional fluorine $\left(9 \mathrm{~b}, \mathrm{~K}_{\mathrm{i}}=338 \mathrm{nM}\right)$ or 3-trifluoromethyl $\left(9 \mathrm{c}, \mathrm{K}_{\mathrm{i}}=166 \mathrm{nM}\right)$ produced similarly active compounds, as did the addition of the 4-chloro $\left(\mathbf{9 d}, \mathrm{K}_{\mathrm{i}}=134 \mathrm{nM}\right)$. Moving to the 3-imidazo[1,5a]pyridine or the 1-imidazo[1,5-a]pyridines with the same $O$-benzyl groups produced active compounds, 9e-h. Addition of a 3-methyl group to the 1-imidazo[1,5-a]pyridine (9i-k) also generated active analogs, with $9 \mathbf{j}\left(\mathrm{K}_{\mathrm{i}}=96 \mathrm{nM}\right)$ being the most potent compound in the series. Moving to the 5$\mathrm{NH}$-benzimidazole compounds we saw a dramatic loss of activity (91-n); however, this activity could be regained by methylating the nitrogen of the indazole $\left(\mathbf{9 o}, \mathrm{K}_{\mathrm{i}}=276 \mathrm{nM} ; \mathbf{9 p}, \mathrm{K}_{\mathrm{i}}=170 \mathrm{nM} ; \mathbf{9 q}, \mathrm{K}_{\mathrm{i}}=\right.$ $201 \mathrm{nM})$. As we had found the 2-indole compound displayed surprising activity on the pyridine moiety in the above series, we incorporated it into this scaffold. The compounds were active against $\mathrm{D}_{4}(\mathbf{9 r}-\mathbf{t})$; however, they did have varying degrees of activity against the other dopamine receptors. Lastly, based on a recent report on the discovery of acetamide based $\mathrm{D}_{4}$ agonists, we incorporated this moiety into our southern portion to evaluate the effect on our scaffold. Interestingly, the acetamide (11a-d) produced varying activity against $\mathrm{D}_{4}$ as well as dopamine receptor selectivity. We did, however, identify an active compound $\left(\mathbf{1 1 d}, \mathrm{K}_{\mathrm{i}}=121 \mathrm{nM}\right)$ that was selective for $\mathrm{D}_{4}$. The same trends for the CNS MPO scores held as previously described for the 3-oxopiperidine analogs, with our most potent 
compound, 9j, having a high score (5.0). Additionally, the 4-oxopiperidine scaffold eliminates the chiral center and thus allows an easier synthetic scheme and diversification.

Table 2. 4-O-piperidine

\begin{tabular}{|c|c|c|c|c|}
\hline Cmpd & Structure & $\begin{array}{c}\mathrm{D}_{4}, \mathrm{~K}_{\mathrm{i}}(\mathrm{nM}) \\
\text { or \% inhibition } \\
\text { at } 10 \mu \mathrm{M}^{a}\end{array}$ & $\begin{array}{c}\text { DR, \% Inh @ } \\
10 \mu \mathrm{M}(\mathrm{nM})\end{array}$ & CNS MPO \\
\hline 1 & & $\begin{array}{c}5.8 \mathrm{nM} \\
\mathrm{pIC}_{50}=-8.30\end{array}$ & $<50 \%$ & 4.7 \\
\hline $9 a$ & & $\begin{array}{c}167.0 \\
\mathrm{pIC}_{50}=6.78\end{array}$ & $<50 \%$ & 5.3 \\
\hline $9 b$ & & $\begin{array}{c}337.5 \\
\mathrm{pIC}_{50}=6.47\end{array}$ & $<50 \%$ & 5.2 \\
\hline $9 \mathrm{c}$ & & $\begin{array}{c}166.1 \\
\mathrm{pIC}_{50}=6.78\end{array}$ & $<50 \%$ & 4.6 \\
\hline $9 \mathrm{~d}$ & & $\begin{array}{c}133.9 \\
\mathrm{pIC}_{50}=6.87\end{array}$ & $\begin{array}{c}\mathrm{D}_{1,2,3}<50 \% \\
\mathrm{D}_{5}=57 \% \\
(>10,000)\end{array}$ & 5.1 \\
\hline $9 \mathrm{e}$ & & $\begin{array}{c}157.6 \\
\mathrm{pIC}_{50}=6.80\end{array}$ & $<50 \%$ & 5.1 \\
\hline $9 \mathrm{f}$ & & $\begin{array}{c}207.8 \\
\mathrm{pIC}_{50}=6.68\end{array}$ & $<50 \%$ & 4.9 \\
\hline $9 \mathrm{~g}$ & & $\begin{array}{c}215.1 \\
\mathrm{pIC}_{50}=6.67\end{array}$ & $<50 \%$ & 5.4 \\
\hline $9 \mathrm{~h}$ & & $\begin{array}{c}165.6 \\
\mathrm{pIC}_{50}=6.78\end{array}$ & $<50 \%$ & 5.5 \\
\hline
\end{tabular}




\begin{tabular}{|c|c|c|c|}
\hline $9 \mathrm{i}$ & $\begin{array}{c}309.1 \\
\mathrm{pIC}_{50}=6.52\end{array}$ & $\begin{array}{c}\mathrm{D}_{1,2,5}<50 \% \\
\mathrm{D}_{3}=60 \% \\
(896.2)\end{array}$ & 4.8 \\
\hline $9 j$ & $\begin{array}{c}95.5 \\
\mathrm{pIC}_{50}=7.02\end{array}$ & $<50 \%$ & 5.0 \\
\hline $9 \mathrm{k}$ & $\begin{array}{c}477.6 \\
\mathrm{pIC}_{50}=6.32\end{array}$ & $<50 \%$ & 5.4 \\
\hline 91 & $\begin{array}{c}1,517.8 \\
\mathrm{pIC}_{50}=5.82\end{array}$ & $<50 \%$ & 4.8 \\
\hline $9 m$ & $\begin{array}{c}1,803.4 \\
\mathrm{pIC}_{50}=5.74\end{array}$ & $\begin{array}{c}\mathrm{D}_{1,2,5}<50 \% \\
\mathrm{D}_{3}=83 \% \\
(948.4)\end{array}$ & 4.7 \\
\hline $9 n$ & $\begin{array}{c}4,279.6 \\
\mathrm{pIC}_{50}=5.37\end{array}$ & $\begin{array}{c}\mathrm{D}_{1,2,5}<50 \% \\
\mathrm{D}_{3}=57 \% \\
(4,079.4)\end{array}$ & 5.4 \\
\hline 90 & $\begin{array}{c}276.0 \\
\mathrm{pIC}_{50}=6.56\end{array}$ & $<50 \%$ & 5.2 \\
\hline $9 p$ & $\begin{array}{c}170.0 \\
\mathrm{pIC}_{50}=6.77\end{array}$ & $<50 \%$ & 4.3 \\
\hline $9 q$ & $\begin{array}{c}200.5 \\
\mathrm{pIC}_{50}=6.70\end{array}$ & $\begin{array}{c}\mathrm{D}_{1,2,5}<50 \% \\
\mathrm{D}_{3}=92 \% \\
(922.8)\end{array}$ & 4.1 \\
\hline $9 \mathrm{r}$ & $\begin{array}{c}322.9 \\
\mathrm{pIC}_{50}=6.49\end{array}$ & $\begin{array}{c}\mathrm{D}_{1,2}<50 \% \\
\mathrm{D}_{3}=76 \% \\
(557.4) \\
\mathrm{D}_{5}=65 \% \\
(3,529.4)\end{array}$ & 2.9 \\
\hline
\end{tabular}




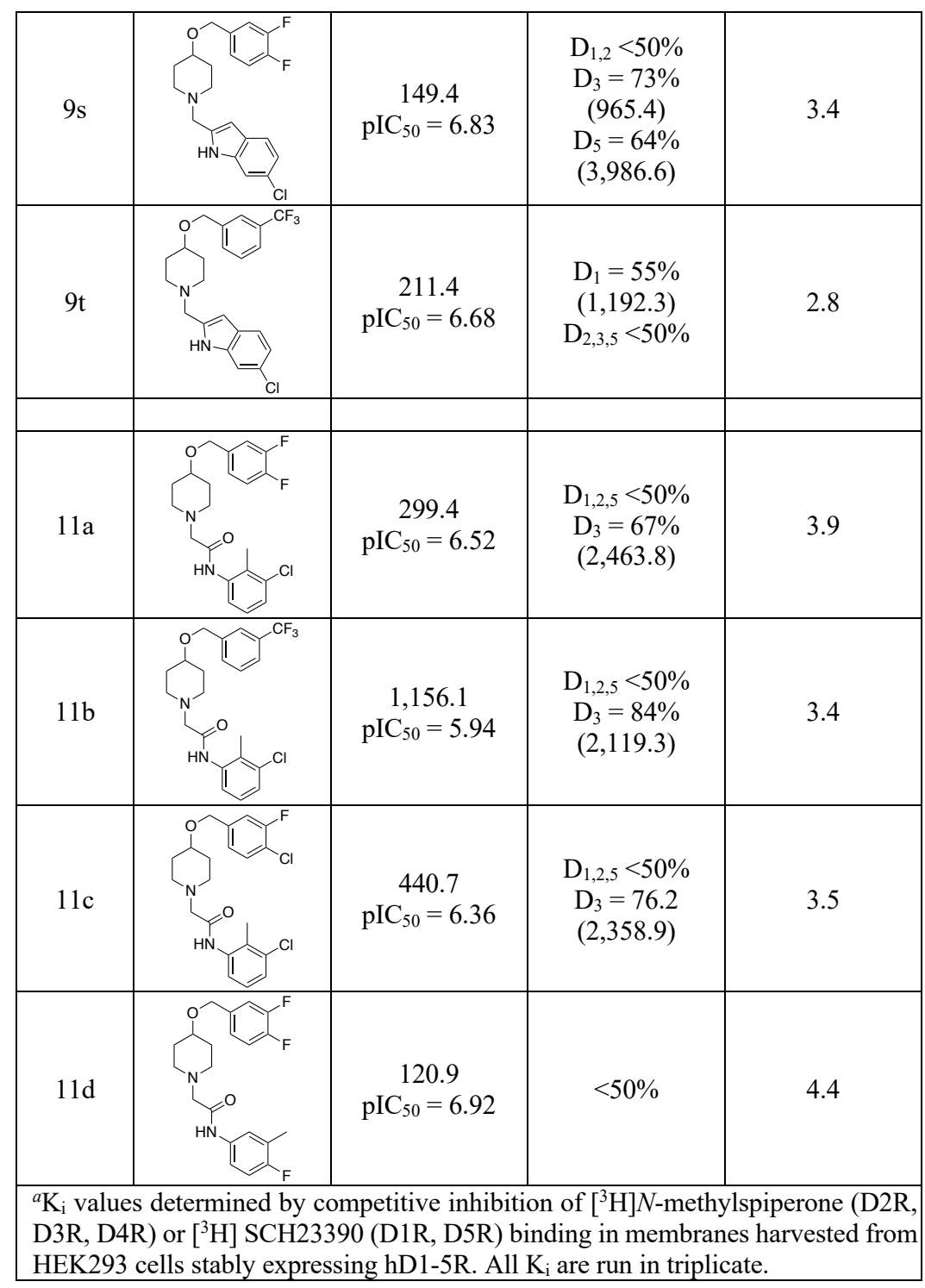

Having evaluated several new compounds around two new scaffolds, we next wanted to take advantage of the recently published X-ray crystal structure of the $\mathrm{D}_{4}$ receptor. ${ }^{20,21}$ Using the published structure (PDB: 5WIU) we were able to dock our compounds using the Schrödinger Drug Discovery Suite (Maestro, Release 2021-3) and then generate ligand interaction poses using Glide (Figure 2). ${ }^{22-24}$ The compounds share similar interactions, namely an Asp115 interaction with the morpholine or piperidine nitrogen, and a $\pi-\pi$ stacking interaction with Phe410 and the benzyl group off the nitrogen. The acetamide function of 11d appears to make an additional H-bonding interaction with Asp115 (Figure 2D); however, this does not appear to provide a favorable interaction as shown by the potency. Interestingly, the morpholine oxygen 
does not show any interactions within the receptor, nor does the side chain oxygen, as can be seen in compounds where we replaced the oxygen with a methylene linker. The presence of the side chain oxygen does play a couple of key roles however: 1 . including the oxygen reduces the cLogP, and 2. it provides a synthetic handle to gain access to more diverse analogs.

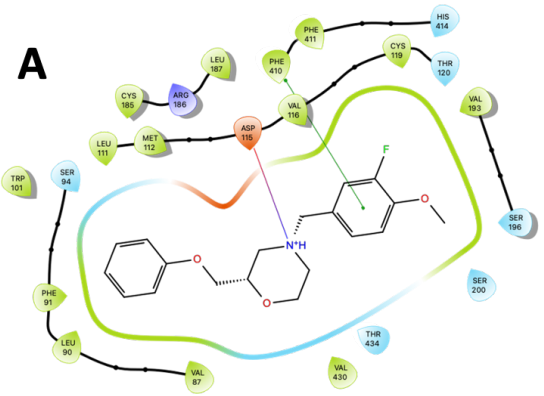

rig

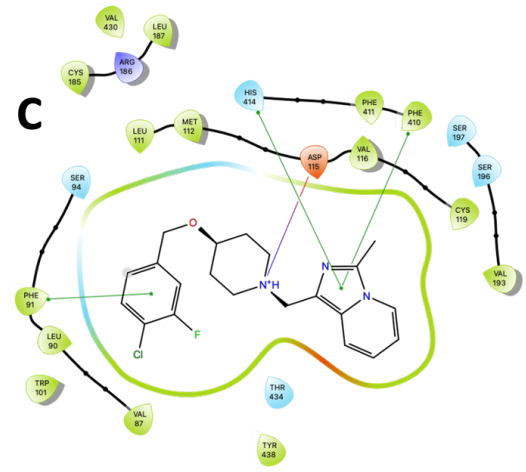

B
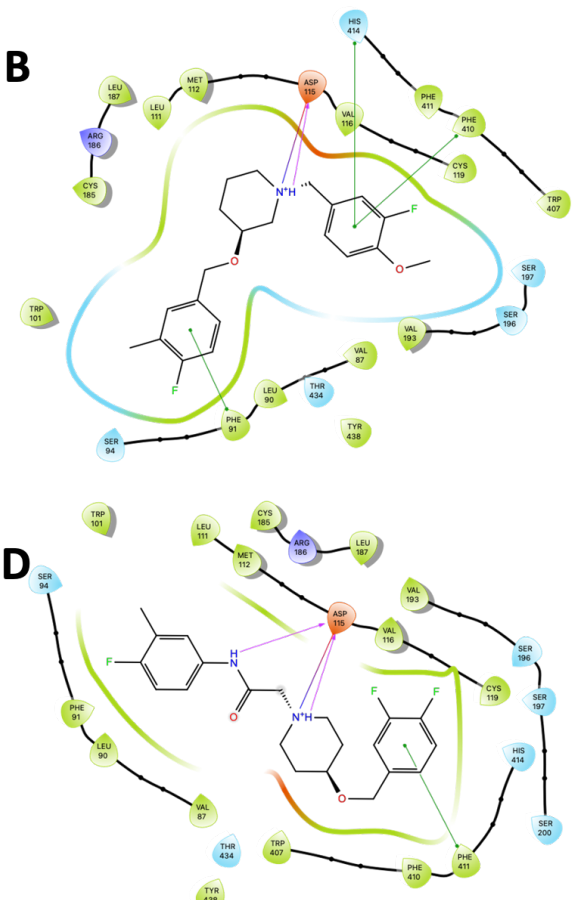

Figure 2. Ligand interaction poses generated using Glide docking software. A. Compound 1, B. Compound 8c, C. Compound 9j, D. Compound 11d.

Next, we further evaluated selected compounds based on liver microsome stability and plasma protein binding (Table 3). ${ }^{25-27}$ We again used 1 as our comparator compound because despite being highly unstable in liver microsomes (human and mouse) it did show good free fraction in both human and mouse. A metabolite ID study on $\mathbf{1}$ indicated that $N$-dealkylation was the major metabolic liability, followed by further $O$-phenyl oxidation of the unsubstituted moiety. Only three of the 3-oxypiperidine analogs were tested $(\mathbf{8 b}, \mathbf{8 i}, \mathbf{8 0})$; however, these represented compounds with varying $N$-alkylated moieties from the substituted $\mathrm{N}$-benzyl to the $\mathrm{N}$-methylimidazopyridine. Moving to the 4-oxopiperidine scaffold reversed this 
trend. Evaluating the $N$-methylimidazo[1,2-a]pyridine showed these compounds to have significantly improved liver microsome stability in both human and mouse. In fact, $9 \mathbf{a}$ and $\mathbf{9 b}$ were tested as stable in human liver microsomes but were modestly stable in mouse liver microsomes. The imidazo[1,5- $a]$ pyridine moieties were not as stable $(\mathbf{9 e}, \mathbf{9 h})$ and addition of a methyl group to block potential oxidation at the carbon adjacent to the two nitrogen atoms did not improve the stability $(\mathbf{9 i}, \mathbf{9 j})$. The $N H$-benzimidazole analogs also displayed improved stability; however, these compounds were not as active $\left(\mathrm{K}_{\mathrm{i}}>1,000 \mathrm{nM}\right)$. The addition of a methyl group to the nitrogen did not impact their stability negatively but did improve the potency by 10 -fold. Lastly, the acetamide analog, 11d, was moderately stable in both human and mouse liver microsomes. As seen in $\mathbf{1}$, most of the compounds tested displayed good free fraction $(>3 \%)$ in both human and mice; although there were some species differences which trended to higher free fraction in mice. Aside from 11d which was not stable in mice plasma, the other compounds were stable in both human and mice plasma when tested.

Table 3. In vitro PK parameters of selected compounds.

\begin{tabular}{|c|c|c|c|c|c|c|c|}
\hline \multirow[t]{2}{*}{ Cmpd } & \multirow{2}{*}{$\begin{array}{c}\mathrm{D}_{4}, \mathrm{~K}_{\mathrm{i}} \\
(\mathrm{nM})\end{array}$} & \multicolumn{4}{|c|}{ Intrinsic clearance $(\mathrm{mL} / \mathrm{min} / \mathrm{kg})^{a, d}$} & \multicolumn{2}{|c|}{$\begin{array}{l}\text { Plasma Protein } \\
\text { Binding }\left(\% f_{\mathrm{u}}\right)^{b, d}\end{array}$} \\
\hline & & $\mathrm{hCL}_{\mathrm{INT}}$ & $\mathrm{hCL}_{\text {HEP }}$ & $\mathrm{mCL}_{\mathrm{INT}}$ & $\mathrm{mCL}_{\mathrm{HEP}}$ & $\mathrm{hPPB}$ & $\mathrm{mPPB}$ \\
\hline 1 & 5.8 & 71.9 & 16.3 & 2128 & 67.8 & 3.1 & 3.7 \\
\hline $8 \mathrm{~b}$ & 169.3 & 272.5 & 18.7 & 1261.3 & 84.1 & 1.1 & 2.6 \\
\hline $8 \mathrm{i}$ & 187.5 & 689.3 & 19.5 & 1402.8 & 84.7 & 0.2 & 8.7 \\
\hline 80 & 165.5 & 621.7 & 19.5 & 5368.8 & 88.6 & 3.9 & 18.1 \\
\hline $9 a$ & 167.0 & $<23.1$ & 10.7 & 380.2 & 72.8 & 7.0 & 35.5 \\
\hline $9 \mathrm{~b}$ & 337.5 & $<20$ & $<10$ & 158.3 & 57.4 & 6.2 & 42.8 \\
\hline $9 \mathrm{c}$ & 166.1 & 44.6 & 13.9 & 309.7 & 69.8 & 1.8 & 17.1 \\
\hline $9 \mathrm{~d}$ & 133.9 & 44.1 & 13.8 & 96.8 & 46.7 & 1.8 & 22.4 \\
\hline $9 \mathrm{e}$ & 157.6 & 212.5 & 18.4 & 916.9 & 82.0 & 1.0 & 1.7 \\
\hline $9 \mathrm{~h}$ & 165.6 & 340.0 & 19.0 & 1261.3 & 84.1 & 2.3 & 40.5 \\
\hline $9 \mathrm{i}$ & 309.1 & 85.3 & 16.3 & 272.0 & 67.7 & 5.2 & 3.6 \\
\hline $9 j$ & 95.5 & 114.5 & 17.1 & 140.3 & 54.9 & 7.1 & 13.2 \\
\hline 91 & $1,517.8$ & 48.3 & 14.2 & 90.4 & 45.1 & 7.7 & 17.1 \\
\hline $9 \mathrm{~m}$ & $1,803.4$ & 32.9 & 12.5 & 76.4 & 41.3 & 2.5 & 16.1 \\
\hline $9 n$ & $4,279.6$ & $<20$ & $<10$ & 93.9 & 46.0 & 22.9 & 40.1 \\
\hline 90 & 170.0 & 42.7 & 13.7 & 85.3 & 43.8 & 0.9 & 5.2 \\
\hline $9 p$ & 276.1 & 32.8 & 12.5 & 103.7 & 48.2 & 3.6 & 16.6 \\
\hline $9 q$ & 200.5 & 63.3 & 15.3 & 85.2 & 43.8 & 1.0 & 5.7 \\
\hline $9 \mathrm{~s}$ & 149.4 & 23.5 & 10.8 & 83.2 & 43.3 & $<0.3$ & 0.4 \\
\hline $9 \mathrm{t}$ & 211.4 & 26.9 & 11.5 & 71.5 & 39.9 & 0.1 & 0.1 \\
\hline $11 \mathrm{~d}$ & 120.9 & 49.5 & 14.3 & 306.2 & 69.6 & 0.5 & $c$ \\
\hline \multicolumn{8}{|c|}{$\begin{array}{l}{ }^{a} \text { Predicted hepatic clearance based on intrinsic clearance in mouse and human liver } \\
\text { microsomes using the well-stirred organ CL model (binding terms excluded). }{ }^{b} f_{\mathrm{u}}=\text { fraction } \\
\text { unbound. }{ }^{c} \text { Unstable in human or mouse plasma. }{ }^{d} \text { In vitro DMPK studies performed at Q2 } \\
\text { Solutions, Indianapolis, IN }\end{array}$} \\
\hline
\end{tabular}


In conclusion, we have identified new 3- and 4-oxopiperidine scaffolds as potent and selective dopamine 4 antagonists. This work builds upon our previous disclosures on chiral morpholines and 4,4difluoropiperidine compounds. Although this scaffold does not impart the same level of activity, chemical optimization has improved human and mouse liver microsome stability. We have also evaluated the scaffolds using the published X-ray crystal structure and have identified the key Asp115 and Phe410 interactions that are present in all the compounds. This analysis will enable further scaffold diversification and chemical optimization. Further profiling and in vivo PK experiments will be reported in due course.

\section{Acknowledgements}

This work was generously supported by a grant from the US National Institutes of Health (NINDS: R01NS119266) to C.R.H. The authors would like to thank Q2 Solutions (Indianapolis, IN USA) for the in vitro DMPK experiments.

\section{References}

1. Jaber, M.; Robinson, S. W.; Missale, C.; Caron, M. G. Dopamine receptors and brain function. Neuropharmacol. 1996, 35, 1503-1519.

2. Zhou, Q.-Y.; Grandy, D. K.; Thambi, L.; Kushner, J. A.; Van Tol, H. H. M.; Cone, R.; Pribnow, D.; Salon, J.; Bunzow, J. R.; Civelli, O. Cloning and expression of human and rat $\mathrm{D}_{1}$ dopamine receptors. Nature 1990, 347, 76-80.

3. Beaulieu, J.-M.; Gainetdinov, R. R. The physiology, signaling, and pharmacology of dopamine receptors. Pharmacol. Rev. 2011, 63, 182-217.

4. Boyd, K. N.; Mailman, R. B. Dopamine receptor signaling and current and future antipsychotic drugs. Handb. Exp. Pharmacol. 2012, 212, 53-86.

5. Hurley, M. J.; Jenner, P. What has been learnt from study of dopamine receptors in Parkinson's disease? Pharm. Therap. 2006, 111, 715-728. 
6. $\quad$ Brisch, R.; Saniotis, A.; Wolf, R.; Bielau, H.; Bernstein, H.-G.; Steiner, J.; Bogerts, B.; Braun, K.; Jankowski, Z.; Kumaratilake, J.; Henneberg, M.; Gos, T. The role of dopamine in schizophrenia from a neurobiological and evolutionary perspective: old fashioned, but still in vogue. Front. Psychiatry 2014, 5, 47 .

7. Nikam, S. S. A., A. K. Evaluation of schizophrenia drugs: a focus on dopaminergic systems. Curr. Opin. Investig. Drugs 2008, 9, 37-46.

8. Tarazi, F. I.; Baldessarini, R. J. Dopamine $\mathrm{D}_{4}$ receptors: significance for molecular psychiatry at the millenium. Mol. Psychiatry 1999, 4, 529-538.

9. Tarazi, F. I.; Zhang, K.; Baldessarini, R. J. Dopamine $\mathrm{D}_{4}$ receptors: beyond schizophrenia. J. Recept. Signal Transduct. Res. 2004, 24, 131-147.

10. Bristow, L. J.; Kramer, M. S.; Kulagowski, J.; Patel, S.; Ragan, C. I.; Seabrook, G. R. Schizophrenia and L-745,870, a novel dopamine D4 receptor antagonist. Trends Pharm. Sci. 1997, 18, 186-188.

11. Lindsley, C. W.; Hopkins, C. R. Return of D4 dopamine receptor antagonists in drug discovery. $J$. Med. Chem. 2017, 60, 7233-7243.

12. Witt, J. O.; McCollum, A. L.; Hurtado, M. A.; Huseman, E. D.; Jeffries, D. E.; Temple, K. J.; Plumley, H. C.; Blobaum, A. L.; Lindsley, C. W.; Hopkins, C. R. Synthesis and characterization of a series of chiral alkoxymethyl morpholine analogs as dopamine receptor 4 (D4R) antagonists. Bioorg. Med. Chem. Lett. 2016, 26, 2481-2488.

13. Sebastianutto, I.; Maslava, N.; Hopkins, C. R.; Cenci, M. A. Validation of an improved scale for rating L-DOPA-induced dyskinesia in the mouse and effects of specific dopamine receptor antagonists. Neurobiol. Dis. 2016, 96, 156-170.

14. Jeffries, D. E.; Witt, J. O.; McCollum, A. L.; Temple, K. J.; Hurtado, M. A.; Harp, J. M.; Blobaum, A. L.; Lindsley, C. W.; Hopkins, C. R. Discovery, characterization and biological evaluation of a novel $(R)$-4,4-difluoropiperidine scaffold as dopamine receptor $4\left(\mathrm{D}_{4} \mathrm{R}\right)$ antagonists. Bioorg. Med. Chem. Lett. 2016, 26, 5757-5764. 
15. Berry, C. B.; Bubser, M.; Jones, C. K.; Hayes, J. P.; Wepy, J. A.; Locuson, C.; Daniels, J. S.; Lindsley, C. W.; Hopkins, C. R. Discovery and characterization of ML398, a potent and selective antagonist of the $\mathrm{D}_{4}$ receptor with in vivo activity. ACS Med. Chem. Lett. 2014, 5, 1060-1064.

16. Abdel-Magid, A. F.; Carson, K. G.; Harris, B. D.; Maryanoff, C. A.; Shah, R. D. Reductive amination of aldehydes and ketones with sodium triacetoxyborohydride. Studies on direct and indirect reductive amination procedures. J. Org. Chem. 1996, 61, 3849-3862.

17. Keck, T. M.; Free, R. B.; Day, M. M.; Brown, S. L.; Maddaluna, M. S.; Fountain, G.; Cooper, C.; Fallon, B.; Holmes, M.; Stang, C. T.; Burkhardt, R.; Bonifazi, A.; Ellenberger, M. P.; Newman, A. H.; Sibley, D. R.; Wu, C.; Boateng, C. A. Dopamine $\mathrm{D}_{4}$ receptor-selective compounds reveal structure-activity relationships that engender agonist efficacy. J. Med. Chem. 2019, 62, 3722-3740.

18. Wager, T. T.; Hou, X.; Verhoest, P. R.; Villalobos, A. Moving beyond rules: the development of a central nervous system multiparameter optimization (CNS MPO) approach to enable alignment of druglike properties. ACS Chem. Neurosci. 2010, 1, 435-449.

19. Wager, T. T.; Chandrasekaran, R. Y.; Hou, X.; Troutman, M. D.; Verhoest, P. R.; Villalobos, A.; Will, Y. Defining desirable central nervous system drug space through the alignment of molecular properties, in vitro ADME, and safety attributes. ACS Chem. Neurosci. 2010, 1, 420-434.

20. Wang, S.; Wacker, D.; Levit, A.; Che, T.; Betz, R. M.; McCorvy, J. D.; Venkatakrishnan, A. J.; Huang, X.-P.; Dror, R. O.; Shoichet, B. K.; Roth, B. L. D 4 dopamine receptor high-resolution structures enable the discovery of selective agonists. Science 2017, 358, 381-386.

21. Lyu, J.; Wang, S.; Balius, T. E.; Singh, I.; Levit, A.; Moroz, Y. S.; O’Meara, M. J.; Che, T.; Algaa, E.; Tolmachova, K.; Tolmachev, A. A.; Shoichet, B. K.; Roth, B. L.; Irwin, J. J. Ultra-large library docking for discovering new chemotypes. Nature 2019, 566, 224-229.

22. Small-Molecule Drug Discovery Suite 2021-3, Schrödinger, LLC, New York, NY, 2021.

23. Friesner, R. A.; Banks, J. L.; Murphy, R. B.; Halgren, T. A.; Klicic, J. J.; Mainz, D. T.; Repasky, M. P.; Knoll, E. H.; Shelley, M.; Perry, J. K.; Shaw, D. E.; Francis, P.; Shenkin, P. S. Glide: a new 
approach for rapid, accurate docking and scoring. 1. Method and assessment of docking accuracy. J. Med. Chem. 2004, 47, 1739-1749.

24. Halgren, T. A.; Murphy, R. B.; Friesner, R. A.; Beard, H. S.; Frye, L. L.; Pollard, W. T.; Banks, J. L. Glide: a new approach for rapide, accurate docking and scoring. 2. Enrichment factors in database screening. J. Med. Chem. 2004, 47, 1750-1759.

25. Obach, R. S. Prediction of human clearance of twenty-nine drugs from hepatic microsomal intrinsic clearance data: an examination of in vitro half-life approach and nonspecific binding to microsomes. Drug Metab. Disp. 1999, 27, 1350-1359.

26. Obach, R. S.; Baxter, J. G.; Liston, T. E.; Silber, B. M.; Jones, B. C.; MacIntyre, F.; Rance, D. J.; Wastall, P. The prediction of human pharmacokinetic parameters from preclinical and in vitro metabolism data. J. Pharmacol. Exp. Ther. 1997, 283, 46-58.

27. Chang, G.; Steyn, S. J.; Umland, J. P.; Scott, D. O. Strategic Use of Plasma and Microsome Binding To Exploit in Vitro Clearance in Early Drug Discovery. ACS Med. Chem. Lett. 2010, 1, 50-63. 